\title{
EFFECTS OF GROWTH OF SOME CYANOPROKARYOTA AND DIATOM SPECIES ON THE GROWTH OF TWO MOSSES
}

\author{
Mohamed Farag, Hesham M. Abd El Fatah*, Hanaa M. Shabaraa, \\ Hanan F. Shaaban
}

Botany Department, Faculty of Science, Ain Shams University, Cairo, Egypt

\begin{abstract}
Cyanoprokaryotic taxa Nostoc paludosum Kützing ex Bornet \& Flahault and Nostoc punctiforme (Kützing) Hariot may have allelopathic effects on two moss taxa, Bryum subapiculatum Hampe and Funaria hygrometrica Hedwig, grown in vitro under $66 \%$ and 99\% percentages of soil water holding capacity. Nostoc filaments destroyed protonema of $B$. subapiculatum and arrested gametophores development of $F$. hygrometrica under these conditions. Colonies of the diatom Navicula cryptocephala var. veneta (Kützing) Grun. grew in a large amount and delayed the growth of B. subapiculatum.
\end{abstract}

Keywords: Allelopathy; Bryophytes; Bryum; Funaria; Navicula; Nostoc.

\section{Introduction}

Most of bryophytes, cyanoprokaryota and diatoms prefer the moist and the shade climatic conditions (Sahu, et al., 2013a). Cyanoprokaryota and diatoms are known to be the most abundant photoautotrophic organisms living in soil (Prescott, 1969). Bryophytes phyllids are in general tinny and mono-layered disposed on the caulid creating suitable space for various xenic inhabitants (Vujičić, et al., 2009; Sabovljević, et al., 2012). Bryophytes-cyanoprokaryota and bryophytes-diatoms associations are natural phenomena recorded in natural growth habitats of bryophytes (El Saadawi and Abou-Elkheir, 1973; AbouElkheir, et al., 1986; 1988; Fletcher, 1991).

El Saadawi and Abou-Elkheir (1973) observed 7 cyanoprokaryotical taxa and 84 diatom taxa in habitats of 16 moss taxa. Anderson and Rushforth (1977) reported various associations with bryophytes and they were usually with diatoms followed by cyanoprokaryota and green algae. Toppo and Susheela (2007) observed 21 algal taxa associated in the rhizoidal zones of three bryophytes. Cyanoprokaryota grow mostly epiphytically on mosses (Solheim and Zielke, 2002; Gentili et al., 2005), while diatoms prefer rhizoidal zone (El Saadawi and Abou-Elkheir, 1973).

According to some evidence, it is suggested that cyanoprokaryota communities can strongly differ with different associated moss species but it 
remains largely unknown to what extent cyanoprokaryota and moss receive mutual benefit from their association (Abou-Elkheir, et al., 1988; Opelt, et al., 2007; Ininbergs, et al., 2011). Fletcher (1991) mentioned that some cyanoprokaryota may discourage competitors of mosses by chemical means; however he added that some mosses grow quite successfully in cultures covered with them. Henriksson and Henriksson (1974) recorded nitrogen fixation by Nostoc muscorum and Anabaena variabilis in soils inhabited by mosses, including Funaria, while Sahu, et al. (2013b) recorded an allelopathic effect of certain cyanoprokaryota on cultured bryophytes, at a Bryophyte Conservatory.

"Allelopathy" is a biological term introduced by Molisch in 1937 then broadened by Rice (1984). The International Allelopathy Society (1996) announced the definition of allelopathy as any processes involving secondary metabolites (allelopathic compounds) produced by plants, microorganisms, fungi and viruses that have positive or negative influence on the growth and development of agriculture and biological systems. Allelopathic compounds play a role in the interactions between the emitter organisms and their direct competitors (Sahu, et al., 2013a) by having various modes of action, from inhibition of photosynthesis to oxidative stress or cellular paralysis (Leflaive and Ten-hage, 2007).

The aim of this paper is to throw light on the effects of certain cyanoprokaryota and diatoms, which were observed during investigation of the phenotypic plasticity of Bryum subapiculatum Hampe and Funaria hygrometrica Hedwig in response to changes in the percentage of soil maximum water holding capacity via in vitro cultivation.

\section{Materials and Methods}

Two samples of $B$. subapiculatum and $F$. hygrometrica taken from in vitro cultivated populations were washed 3 times by sterilized distilled water. Each moss sample was divided into nine equal portions; each portion consists of 10 individual gametophores. Each portion was propagated in a transparent plastic container of $250 \mathrm{ml}^{3}$ over a $5 \mathrm{~mm}$ thick film of sterilized fine ( $300 \mu$ particle size) garden soil wetted with a certain amount of sterilized distilled water. Soil and distilled water were sterilized by autoclaving for 21 minutes at 15 psi (pressure per square inch). The amounts of the used sterilized distilled water were the same for the two mosses and the percentages of soil water holding capacities (SWHC) were as follow: 1) Three replicates of half maximum percentage (33\%). 2) Three replicates of maximum percentage (66\%). 3) Three replicates of flooding percentage $(99 \%)$. The percentage of maximum water holding capacity was calculated by equation according to (Nagornyy, 2013):

Egyptian J. of Phycol. Vol. 15, 2014 


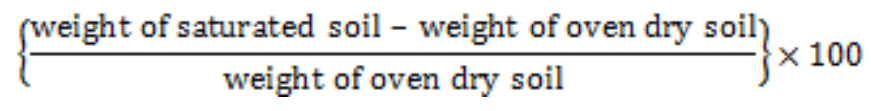

The 18 containers ( 9 for each species) were kept in a plant growth chamber (model V3-DM; Vision scientific company Ltd, Korea) under controlled conditions of alternating light/dark periods of $16 / 8 \mathrm{hrs}$ under white illumination with intensity of $9200 \mathrm{Lux}$ and fluctuant temperature of $25 / 18^{\circ} \mathrm{C} \pm 2^{\circ} \mathrm{C}$ between light and dark, respectively. The containers were checked up frequently for one month but photographed only every 10 days.

Although sterilization of soil and moss samples was carried out, there was noticeable algal growth (scum or colonies). Algal samples were collected from the soil of the 18 containers and preserved in $4 \%$ formalin then they were examined using trinocular microscope (Reichert).

\section{Results}

The growth of B. subapiculatum was slow as it was in the form of only protonema. Except, a few buds observed at 66\% SWHC after 20 days, no gametophores were observed during the 30 days of study. The growth of either cyanoprokaryota or diatoms covered the majority of soil surface under $66 \%$ and 99\% SWHC, while just few colonies of diatoms were observed beneath the inoculated gametophores under 33\% SWHC. The growth of B. subapiculatum protonemata with either cyanoprokaryota or diatoms in each replicate of the three studied percentages after 10,20 and 30 days are summarized in Table (1).

Table (1) the growth of Bryum subapiculatum protonema and the presence of Cyanoprokaryota (C) and diatoms (D) in each container in different percentages of water holding capacity: half maximum (33\%); maximum (66\%); and flooding (99\%) capacity in each replicate.

(no growth (-); weak protonemal growth (+); vigorous protonemal growth (++); destroyed protonema $( \pm)$ )

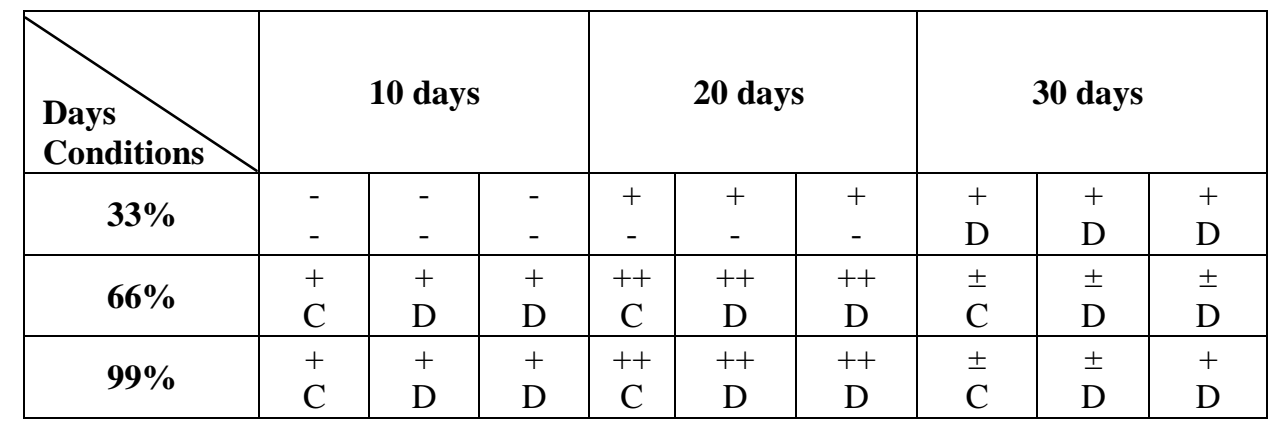


As shown in Table 1, the growth of mosses in the majority of containers was combined with either scum of cyanoprokaryota or colonies of diatoms, which grew on the surface of the soil, over and along the cultivated mosses and around developed protonema. At 33\% SWHC, very small diatom colonies were observed around the developed protonema of B. subapiculatum after 30 days and did not cause any damage (Plate I, Fig. 2). The scum and the colonies were observed during the first 10 days with $66 \%$ and $99 \%$ SWHC. Their destructive effects on the growth of protonema of B. subapiculatum appeared after 20 days and onwards as the growth and spreading of cyanoprokaryota or diatoms increased with time. Protonema was mostly destroyed after 30 days under both conditions (Plate I; Figs. 4, 6.).

Microscopic investigation showed that the scum was formed by filaments of two cyanoprokaryota namely Nostoc paludosum Kützing ex Bornet \& Flahault and Nostoc punctiforme (Kützing) Hariot, while the colonies were formed by the diatom Navicula cryptocephala var. veneta (Kützing) Grun.

On the other hand, the growth of $F$. hygrometrica was fast in comparison with $B$. subapiculatum; buds were developed from protonema and then developed to gametophores within 10 days. The number of developed gametophores was more or less equal after 10 days under the three percentages of water holding capacity. Scum of $N$. paludosum and $N$. punctiforme were present in all replicates under 66\% and 99\% SWHC but were absent in case of 33\% SWHC. The scum appeared during the first 10 days and the largest amount was at $99 \%$ SWHC. No diatoms grew with $F$. hygrometrica. The three studied percentages of SWHC after 10, 20 and 30 days are summarized in Table (2).

Table (2) the growth of Funaria hygrometrica gametophores and the presence of Cyanoprokaryota (C) in each container in different percentages of water holding capacity: half maximum (33\%); maximum (66\%); and flooding (99\%) capacity in each replicate.

(Number of gametophores $\leq 15(+)$; 15-29 (++); 30-49 (+++); 50-100 (++++))

\begin{tabular}{|c|c|c|c|c|c|c|c|c|c|}
\hline & \multicolumn{3}{|c|}{10 days } & \multicolumn{3}{c|}{20 days } & \multicolumn{3}{c|}{30 days } \\
Days & \multicolumn{3}{|c|}{} & \multicolumn{3}{|c|}{} \\
\hline \multirow{2}{*}{$33 \%$} & + & + & + & ++ & ++ & +++ & ++++ & ++++ & ++++ \\
& - & - & - & - & - & - & - & - & - \\
\hline \multirow{2}{*}{$66 \%$} & + & + & + & ++ & ++ & +++ & ++ & ++ & +++ \\
& $\mathrm{C}$ & $\mathrm{C}$ & $\mathrm{C}$ & $\mathrm{C}$ & $\mathrm{C}$ & $\mathrm{C}$ & $\mathrm{C}$ & $\mathrm{C}$ & $\mathrm{C}$ \\
\hline \multirow{2}{*}{$\mathbf{9 9 \%}$} & + & + & + & + & + & + & + & + & + \\
& $\mathrm{C}$ & $\mathrm{C}$ & $\mathrm{C}$ & $\mathrm{C}$ & $\mathrm{C}$ & $\mathrm{C}$ & $\mathrm{C}$ & $\mathrm{C}$ & $\mathrm{C}$ \\
\hline
\end{tabular}


Table 2 shows that under 33\% SWHC condition, cyanoprokaryota were not observed on the surface of soil with $F$. hygrometrica or on the gametophores through the period of study (Plate II; Figs.7, 8) that was companied by vigorous growth of $F$. hygrometrica which was expressed by large number of developed gametophores. Under $66 \% \mathrm{SWHC}$, the growth of $F$. hygrometrica was moderate and accompanied by both $N$. paludosum and $N$. punctiforme which appeared as blue green gelatinous scum spreading on the soil and gametophytes surface. Under $99 \%$ SWHC, N. paludosum was dominant over N. punctiforme and was present in a large amount (Plate II; Fig.11), which arrested the production of new gametophores of $F$. hygrometrica so it`s growth remained weak.

\section{Discussion}

The sterilization of soil was carried out for 21 minutes at $15 \mathrm{psi}$, but some algal spores may still be attached to the mosses body after washing by sterile distilled water. So that the growth of Nostoc spp. and Navicula sp. was observed during investigation of the response of $B$. subapiculatum and $F$. hygrometrica to changes in the percentage of soil maximum water holding capacity via in vitro cultivation. The results shown that, as the percentage of soil water holding capacity increased the algal growth increased, which coincided with results obtained by Poulíčková, et al. (2003). Effects of cyanoprokaryota and diatom appeared mainly under $66 \%$ and $99 \%$ SWHC. The filaments of Nostoc paludosum and Nostoc punctiforme destroyed protonema of B. subapiculatum and arrested gametophores development of $F$. hygrometrica at $66 \%$ and $99 \%$ SWHC. The colonies of Navicula cryptocephala var. veneta when grew in a large amount, delayed the growth of B. subapiculatum indirectly via covering soil surface at the same conditions.

Cyanoprokaryota are known to produce a wide array of toxins (International Allelopathy Society, 1996). Indeed, several cases were reported in which cyanoprokaryotic toxins exerted inhibitory effects on photoautotrophs and these cyanotoxins seem to represent allelochemicals directed against competing organisms (Abe, et al., 1996; Sedmak and Kosi, 1998; Pflugmacher, 2002; Gehringer, et al., 2003). Nostoc spp. could synthesize nostocyclamides, relatively small cyclic peptides, which inhibit the growth of other Cyanoprokaryota and microalgae (Todorova et al., 1995; Jüttner, et al., 2001). Schuster (1992) mentioned that many bryophytes with symbiotic Nostoc tend to show a lot of dieback and their gametophytes becoming semi decayed.

Based on that, the destruction of protonema of B. subapiculatum and the stopping of development of new gametophores of $F$. hygrometrica may be explained as an allelopathic effect of the two Nostoc species; N. paludosum and N. punctiforme on the two moss taxa. 




Plate (I) Differences in the growth of B. subapiculatum under three different percentages $(33 \%, 66 \%$ and $99 \%)$ of soil water holding capacity after 20 and 30 days. Arrow in fig. 2 points to diatom scum beneath the inoculated gametophytes. 


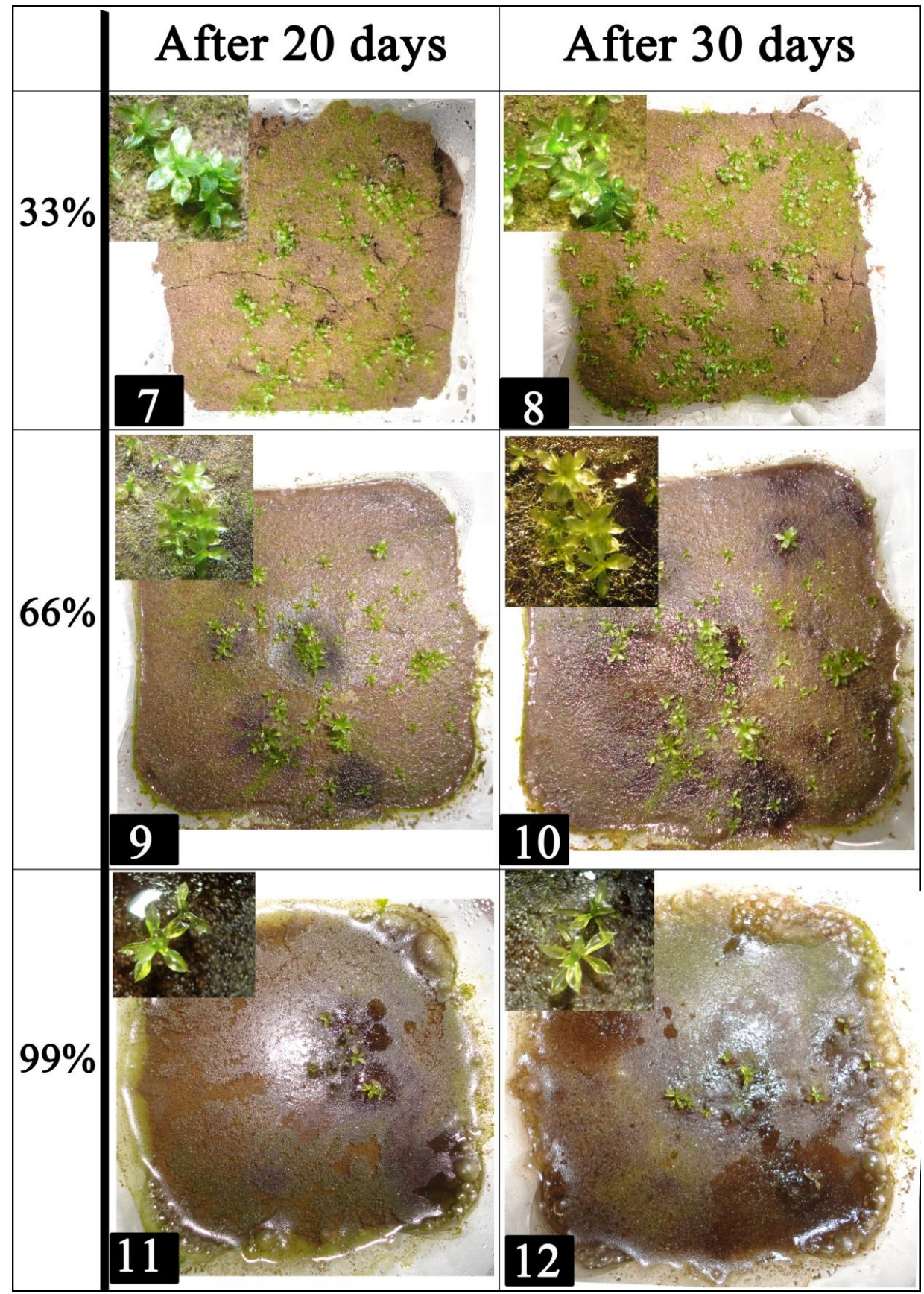

Plate (II) Differences in the growth of $F$. hygrometrica under three different percentages $(33 \%, 66 \%$ and $99 \%)$ of soil water holding capacity after 20 and 30 days. 
Comparing results presented in tables 1 and 2, F. hygrometrica seems to tolerate the stressful conditions more than B. subapiculatum (see also Shaw, 1990). The decline of growth of $F$. hygrometrica under $99 \%$ SWHC may be due to flourished growth of cyanoprokaryota and easy transfer of allelochemical toxins in water.

Navicula cryptocephala was recorded as the dominant diatom in natural habitats of 8 moss species (EI Saadawi and Abou-Elkheir, 1973); however it had inhibitory effect on B. subapiculatum in 66\% and 99\% SWHC. This may represent the indirect inhibitory effect of diatoms. Sahu, et al., (2013a) mentioned that algae affect the growth of mosses by formation of algal growth that caused deficiency of oxygen in the soil and death of the young protonemata.

\section{Acknowledgements}

Authors are grateful to Prof. Wagieh El Saadawi, Botany Department, Faculty of Science, Ain Shams University for stimulating discussions and valuable comments.

\section{References}

Abe, T.; Lawson, T.; Weyers, J. D. B. and Codd, G. A. (1996). Microcystin-LR inhibits photosynthesis of Phaseolus vulgaris primary leaves: implications for current spray irrigation practice. New Phytol. 133: 651658.

Abou-Elkheir, W. S.; El Saadawi, W. E. and Darwish, M. H. (1986). A peculiar algal-moss association from El- Giza, Egypt. Arab Gulf J. scient. Res., 4 (1): 69-75.

Abou-Elkheir, W. S.; El Saadawi, W. E. and Darwish, M. H. (1988). Observations on algal-moss associations. Journ. Hattori Bot. Lab., 65: 303-309.

Anderson, D. C. and Rushforth, S. R. (1977). The Cryptogamic flora of desert soil crust in southern Utah: U.S.A. Nova Hedwigia, 28: 691-729.

El Saadawi, W. E. and Abou-Elkheir, W. S. (1973). On some Egyptian mosses and the algal flora in their habitats. Proc. Egypt. Acad. Sci., 26:125-136.

Fletcher, M. (1991). Moss Grower's Handbook: An Illustrated Beginner's Guide to Finding, Naming and Growing Over 100 Common British Species, Berkshire, UK, Seventy Press.

Gehringer, M. M.; Kewada, V.; Coates, N. and Downing, T. G. (2003). The use of Lepidium sativum in a plant bioassay system for the detection of microcystin-LR. Toxicon, 41: 871-876.

Gentili, F.; Nilsson, M-C.; Zackrisson, O.; DeLuca, T. H. and Sellstedt, A. (2005). Physiological and molecular diversity of feather moss associative N2-fixing cyanobacteria. Journal of Experimental Botany, 56: 3121-3127. 
Henriksson, L. E. and Henriksson, E. (1974). Studies in the nitrogen cycle of Surtsey in 1972. Surtsey Res. Progr. Rep., 7: 36-44.

Ininbergs, K.; Bay, G.; Rasmussen, U.; Wardle, D. A. and Nilsson M-C. (2011). Composition and diversity of nifH genes of nitrogen-fixing cyanobacteria associated with Boreal forest feather mosses. New Phytologist, 192: 507-517.

International Allelopathy Society (1996). First World Congress on Allelopathy. A science for the future. Cadiz, Spain.

Jüttner, F.; Todorova, A. K.; Walch, N. and Philipsborn W.V. (2001). Nostocyclamide M: A cyanobacterial cyclic peptide with allelopathic activity from Nostoc 31. Phytochemistry, 57: 613-619.

Leflaive, J and Ten-hage, L. (2007). Algal and cyanobacterial secondary metabolites in freshwaters: a comparison of allelopathic compounds and toxins. Freshwater Biology, 52(2): 199-214.

Molisch, H. (1937). Der Einfluss einer Pflanze auf die andere: Allelopathie. G. Fisher Verlag, Jena.

Nagornyy, V. D. (2013). A text book: soil and plant Laboratory analysis. Moscow Peoples' Friendship University of Russia.

Opelt, K.; Berg, C. and Berg, G. (2007). The bryophyte genus Sphagnum is a reservoir for powerful and extraordinary antagonists and potentially facultative human pathogens. Fems Microbiology Ecology, 61: 38-53.

Pflugmacher, S. (2002). Possible allelopathic effects of cyanotoxins, with reference to microcystin LR, in aquatic ecosystems. Environ. Toxicol., 17: 407-413.

Poulíčková, A.; Bogdanová, K.; Hekera, P. and Hájková, P. (2003). Epiphytic diatoms of the spring fens in the flysh area of the Western Carpathians. Biologia, Bratislava, 58(4): 749-757.

Prescott, G. W. (1969). The algae: A review. Nelson and Sons, London.

Rice, E. L. (1984). Allelopathy, 2nd ed., Academic Press, London.

Sabovljević, M. S.; Papp, B.; Sabovljević, A.; Vujičić, M.; Szurdoki, E. and Segarra-Moragues, J. G. (2012). In vitro micropropagation of rare and endangered moss Entosthodon hungaricus (Funariaceae). Biosci. J., Uberlândia, 28 (4): 632-640.

Sahu, V.; Toppo, K.; Suseela, M. R. and Asthana, A. K. (2013a). Allelopathic effect of Stichococcus bacillaris Nageli (Green Alga) on the growth of two bryophytes. Archive for Bryology, 162: 1-4.

Sahu, V.; Toppo, K.; Suseela, M. R. and Asthana, A. K. (2013b). Effect of cyanobacterial growth on Bryophytes growing in Conservatory. Archive for Bryology, 172:1-6.

Schuster, R. M. (1992). The Hepaticae and Anthocerotae of North America East of the Hundredth meridian. Chicago.

Sedmak, B. and Kosi, G. (1998). The role of microcystins in heavy cyanobacterial bloom formation. J. Plankton Res., 20: 691-708.

Egyptian J. of Phycol. Vol. 15, 2014 
Shaw, A. J. (1990) Intraclonal variation in morphology, growth rate, and copper tolerance in the moss, Funaria hygrometrica. Evolution, 44: 441-447.

Solheim, B. and Zielke, M. (2002). Associations between cyanobacteria and mosses. In: Rai A. N., Bergman, B., Rasmussen, eds. cyanobacteria in symbiosis. Dordrecht: Kluwer Academic Publishers 37-152.

Todorova, A. K.; Jüttner, F.; Linden, A.; Pluess, T. and Philipsborn, W. V. (1995). Nostocyclamide: A new macrocyclic, thiazole-containing allelochemical from Nostoc sp. 31 (cyanobacteria). J. Org. Chem., 60: 7891-7895.

Toppo, K. and Susheela, M. R. (2007). A preliminary report on Bryophyte and algal associations. In: Nath, V. and Asthana, A. K. (eds), Current trends in Bryology. Bishen Singh and Mahendra Pal Singh, Dehra Dun, India, pp. 279-286.

Vujičić, M.; Sabovljević, A. and Sabovljević, M. (2009). Axenically culturing the bryophytes: a case study of the moss Dicranum scoparium Hedw. (Dicranaceae, Bryophyta). Botanica Serbica, 33(2): 137-140.

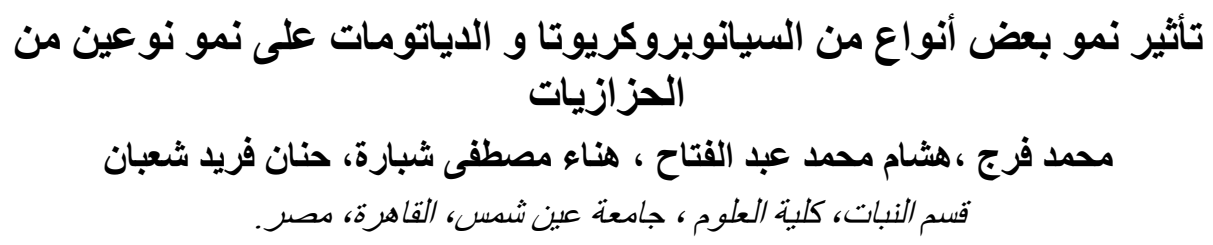

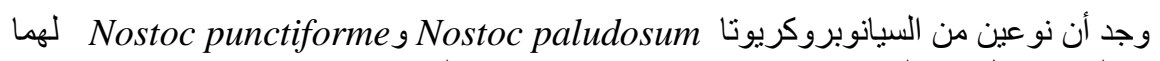

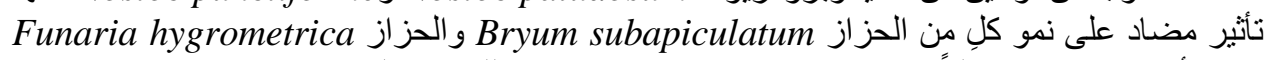

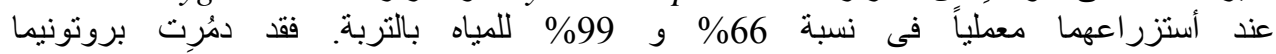

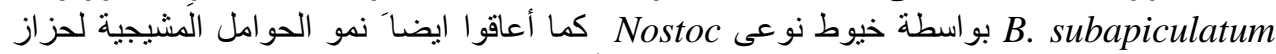

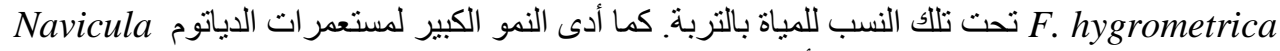

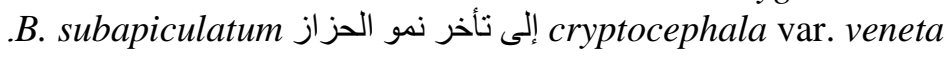

